\title{
HESSD
}

\section{Impact of snow gliding on soil redistribution for a sub-alpine area in Switzerland}

\author{
K. Meusburger ${ }^{1}$, G. Leitinger ${ }^{2}$, L. Mabit ${ }^{1}$, M. H. Mueller ${ }^{1}$, and C. Alewell ${ }^{1}$ \\ ${ }^{1}$ Environmental Geosciences, University of Basel, Basel, Switzerland \\ ${ }^{2}$ Institute of Ecology, University of Innsbruck, Innsbruck, Austria
}

Received: 15 May 2013 - Accepted: 17 June 2013 - Published: 18 July 2013

Correspondence to: K. Meusburger (katrin.meusburger@unibas.ch)

Published by Copernicus Publications on behalf of the European Geosciences Union.

\section{Impact of snow gliding on soil redistribution}

K. Meusburger et al.

Title Page
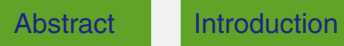

Conclusions References

Tables Figures

14

4

Back

Full Screen / Esc

Printer-friendly Version

Interactive Discussion 


\section{Abstract}

The aim of this study is to assess the importance of snow gliding as soil erosion agent for four different land use/land cover types in a sub-alpine area in Switzerland. The 14 investigated sites are located close to the valley bottom at approximately 1500 ma.s.l., 5 while the elevation of the surrounding mountain ranges is about $2500 \mathrm{~m}$ a.s.l. We used two different approaches to estimate soil erosion rates: the fallout radionuclide ${ }^{137} \mathrm{Cs}$ and the Revised Universal Soil Loss Equation (RUSLE). The RUSLE model is suitable to estimate soil loss by water erosion, while the ${ }^{137} \mathrm{Cs}$ method integrates soil loss due to all erosion agents involved. Thus, we hypothesise that the soil erosion rates deter10 mined with the ${ }^{137} \mathrm{Cs}$ method are higher and that the observed discrepancy between the erosion rate of RUSLE and the ${ }^{137} \mathrm{Cs}$ method is related to snow gliding. Cumulative snow glide distance was measured for the sites in the winter 2009/2010 and modelled for the surrounding area with the Spatial Snow Glide Model (SSGM). Measured snow glide distance range from 0 to $189 \mathrm{~cm}$ with lower values for the north exposed slopes.

15 We observed a reduction of snow glide distance with increasing surface roughness of the vegetation, which is an important information with respect to conservation planning and expected land use changes in the Alps. Our hypothesis was confirmed, the difference of RUSLE and ${ }^{137}$ Cs erosion rates was correlated to the measured snow glide distance $\left(R^{2}=0.73 ; p<0.005\right)$. A high difference (lower proportion of water erosion compared to total net erosion) was observed for high snow glide rates and vice versa. The SSGM reproduced the relative difference of the measured snow glide values between different land use/land cover types. The resulting map highlights the relevance of snow gliding for large parts of the investigated area. Based on these results, we conclude that snow gliding is a key process impacting soil erosion pattern and magnitude
HESSD

10, 9505-9531, 2013

Impact of snow gliding on soil redistribution

K. Meusburger et al.

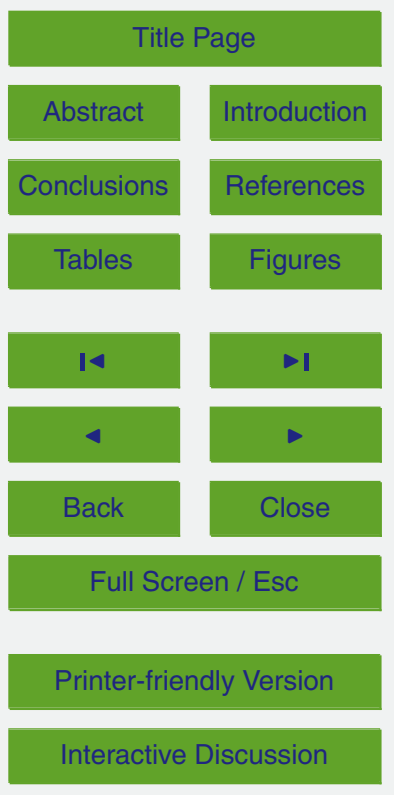




\section{Introduction}

While rainfall is a well-known agent of soil erosion, the erosive forces of snow movements are hardly known. Particularly wet avalanches can yield enormous erosive forces that are responsible for major soil loss (Gardner, 1983; Ackroyd, 1987; Bell et al., 1990;

5 Jomelli and Bertran, 2001; Heckmann et al., 2005; Fuchs and Keiler, 2008; Freppaz et al., 2010) also in the avalanche release area (Ceaglio et al., 2012).

Besides avalanches another important process of snow movement affecting the soil surface is snow gliding (In der Gand and Zupancic, 1966). Snow gliding is the slow ( $\mathrm{mm}$ to $\mathrm{cm}$ per day) downhill motion of a snowpack over the ground surface caused by the stress of its own weight (McGraw-Hill and Parker, 2002). Snow gliding predominantly occurs on south-east to south-west facing slopes with slope angles between $30-40^{\circ}$ (In der Gand and Zupancic, 1966; Leitinger et al., 2008). Two main factors that control snow glide rates are (i) the wetness of the boundary layer between the snow and soil cover and (ii) the ground surface roughness determined by the vegetation cover and rocks (McClung and Clarke, 1987; Newesely et al., 2000). So far, only few studies investigated the effect of snow gliding on soil erosion (Newesely et al., 2000; Leitinger et al., 2008). A major reason for this shortcoming is the difficulty to obtain soil erosion rates caused by snow processes. In steep sub-alpine areas soil erosion records (e.g. with sediment traps) are restricted to the vegetation period because avalanches and snow gliding can irreversibly damage the experimental design (Konz et al., 2012).

Recently first physically based attempts to model the erosive force of wet avalanches were done (Confortola et al., 2012). No similar model exists for snow gliding. However, the potential maximum snow glide distance during a targeted period can be modelled with the empirical spatial snow glide model (SSGM) (Leitinger et al., 2008). The mod25 elling of this process is important to evaluate the impact of the snow glide process on soil erosion at larger scale.

Soil erosion rates can be obtained by direct quantification of sediment transport in the field, by fallout radionuclides (FRN) based methods (e.g. Mabit et al., 1999; Ben-
HESSD

10, 9505-9531, 2013

Impact of snow gliding on soil redistribution

K. Meusburger et al.

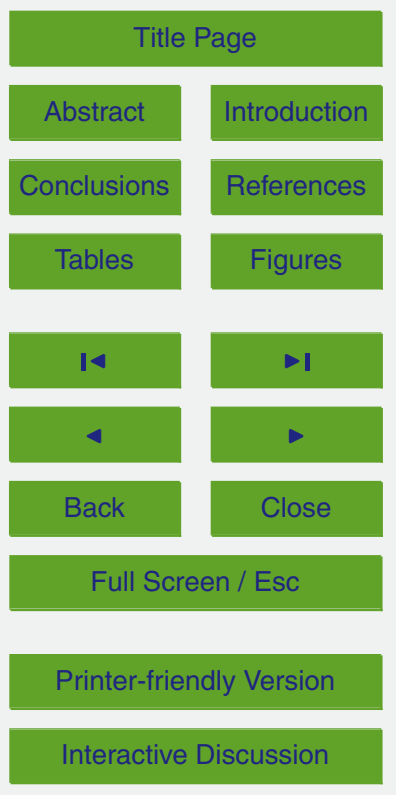


mansour et al., 2013; Meusburger et al., 2013) and by soil erosion models (Nearing et al., 1989; Merritt et al., 2003). Since the end of the 1970's empirical soil erosion models such as the Universal Soil Loss Equation (USLE; Wischmeier and Smith, 1965; Wischmeier and Smith, 1978), and its refined versions the Revised USLE (RUSLE; Re5 nard et al., 1997) and the Modified USLE (MUSLE; Smith et al., 1984), have been used worldwide to evaluate soil erosion magnitude under various conditions (Kinnell, 2010). These well-known models allow the assessment of sheet erosion and rill/inter-rill erosion under moderate topography. However, they do not integrate erosion processes associated with wind, mass movement, tillage, channel or gully erosion (Risse et al., 10 1993; Mabit et al., 2002; Kinnell, 2005) and also snow impact due to movement or melting is not considered (Konz et al., 2009). Several models have been tested for steep alpine sites with the result that RUSLE is reproduced the magnitude of soil erosion, the relative pattern and the effect of the vegetation cover most plausible (Konz et al., 2010; Meusburger et al., 2010b). The erosion rate derived from RUSLE corresponds to water erosion induced by rainfall and surface runoff and hence in our site to the soil erosion processes during the summer season without significant influence of snow processes.

In contrast, the translocation of FRN reflects all erosion processes by water, wind and snow during summer and winter season and thus is an integrated estimate of the total net soil redistribution rate since the 1950s (the start of the global fallout deposit). 20 Anthropogenic fallout radionuclides (e.g. ${ }^{137} \mathrm{Cs},{ }^{134} \mathrm{Cs}$ ) have been used worldwide since decades to assess the magnitude of soil erosion and sedimentation processes (Mabit and Bernard, 2007; Mabit et al., 2008; Matisoff and Whiting, 2011). The most wellknown conservative and validated anthropogenic radioisotope used to investigate soil redistribution and degradation is ${ }^{137} \mathrm{Cs}$ (Mabit et al., 2013).

For (sub-)alpine areas the different soil erosion processes captured by RUSLE and the ${ }^{137} \mathrm{Cs}$ method result in different erosion rates (Konz et al., 2009; Juretzko, 2010; Alewell et al., 2013). However, this difference might also be due to several other reasons such as the error of both approaches, the non-suitability of the RUSLE model for this specific environment and/or the erroneous estimation of the initial fallout of ${ }^{137} \mathrm{Cs}$.

\section{HESSD}

$10,9505-9531,2013$

Impact of snow gliding on soil redistribution

K. Meusburger et al.

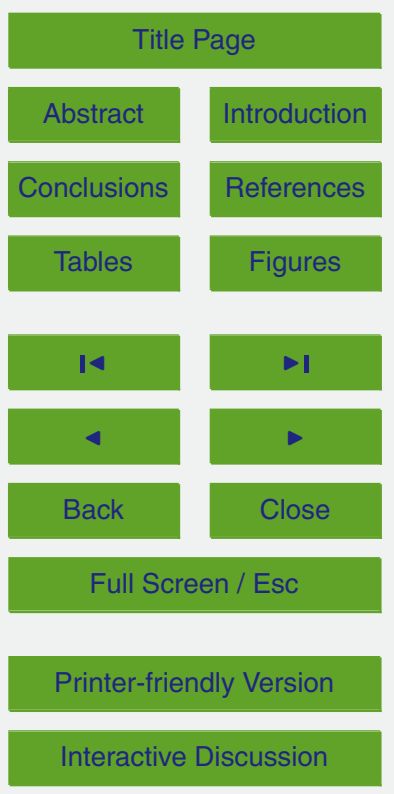


In this study, we aim to investigate, whether the observed discrepancy between erosion rates estimated with RUSLE and the ones provided by the ${ }^{137} \mathrm{Cs}$ method can be at least partly attributed to snow gliding processes. Since vegetation cover affects snow gliding, four different sub-alpine land use/land cover types were investigated. The sec5 ond objective of our research is to assess the relevance of snow gliding processes at catchment scale using the Spatial Snow Glide Model (SSGM).

\section{Materials and methods}

\subsection{Site description}

The study sites are located in Central Switzerland (Canton Uri) in the Ursern Valley 10 (Fig. 1). The elevation of the W-E extended valley ranges from 1400 up to 2500 ma.s.I. The mean annual rainfall, averaged between 1986 and 2008, is $1516 \mathrm{~mm}$. The mean air temperature measured at an altitude of about $1480 \mathrm{~m}$ a.s.l is $3.1^{\circ} \mathrm{C}$ (MeteoSchweiz). The valley is snow covered from November to April with a mean annual snowfall of $443 \mathrm{~mm}$ in the period 1986 to 2008 . Drainage of the basin is usually controlled by snowmelt from May to June. Important contribution to the flow regime takes place during early autumn floods. The land use is characterised by hayfields near the valley bottom (from 1400 to approximately 1600 ma.s.I.) and pasturing further upslope. Siliceous slope debris and moraine material is dominant at our sites, and forms Cambic Podzols (Anthric) and Podzols (Anthric) classified after IUSS Working Group (2006).

Of the 14 experimental sites, 9 are located at the south-facing slope and 5 at the north-facing slope at altitudes between 1450 and 1600 ma.s.l. Four different land use/cover types with 3-5 replicates each were investigated: hayfields (h), pastures (p), pastures with dwarf shrubs (pw), and abandoned grassland covered with Alnus viridis (A). Vegetation of hayfields is dominated by Trifolium pratense, Festuca, Thymus 25 serpyllum and Agrostis capillaries. For the pastured grassland Glubelaria cordifolia, Festuca sp. and T. serpyllum dominate. Pastures with dwarf shrubs are dominated by
HESSD

$10,9505-9531,2013$

Impact of snow gliding on soil redistribution

K. Meusburger et al.

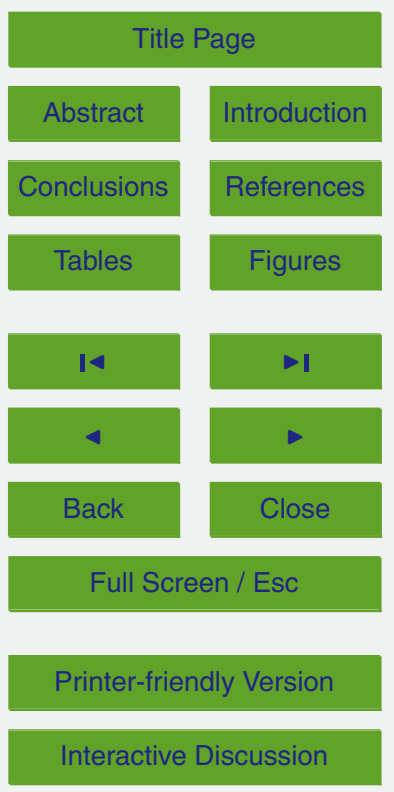


Calluna vullgaris, Vaccinium myrtillus, Festuca violacea, Agrostis capillaries and T. serpyllum. At pasture sites of the south exposed slope, which are stocked from June to September, cattle trails traverse to the main slope direction.

\subsection{Snow glide measurement}

5 We measured cumulative snow glide distances with snow glide shoes for the winter 2009/2010. The snow glide shoe equipment was similar to the set-up used by In der Gand and Zupancic (1966), Newesely et al. (2000) and Leitinger et al. (2008). However, no data logger was used to capture the snow glide rates for specific time intervals during the winter. The set-up consisted of a glide shoe and a buried weather-proof box with a wire drum. Displacement of the glide shoe causes the drum to unroll the wire. The total unrolled distance was measured in spring after snowmelt. To prevent entanglement with the vegetation, the steel wire was protected by a flexible plastic tube.

\subsection{Assessment of soil redistribution pattern based on RUSLE and the ${ }^{137} \mathrm{Cs}$ method}

For 7 sites, RUSLE and ${ }^{137} \mathrm{Cs}$ based erosion rates were available from Konz et al. (2009) and for the 6 additional sites we applied the same methods for soil erosion assessment with ${ }^{137} \mathrm{Cs}$ and RUSLE than in Konz et al. (2009). The ${ }^{137} \mathrm{Cs}$ measurements were decay corrected for comparison purpose.

\subsection{1 ${ }^{137} \mathrm{Cs}$ to assess total net soil redistribution}

A 2 inch $\times 2$ inch Nal-scintillation detector (Sarad, Dresden, Germany) was used to measure the in-situ ${ }^{137} \mathrm{Cs}$ activity. The detector was mounted perpendicular to the ground at a height of $25 \mathrm{~cm}$ to reduce the radius of the investigated area to $1 \mathrm{~m}$. Measurement time was set at $3600 \mathrm{~s}$ and each site was measured three times.

\section{HESSD}

10, 9505-9531, 2013

Impact of snow gliding on soil redistribution

K. Meusburger et al.

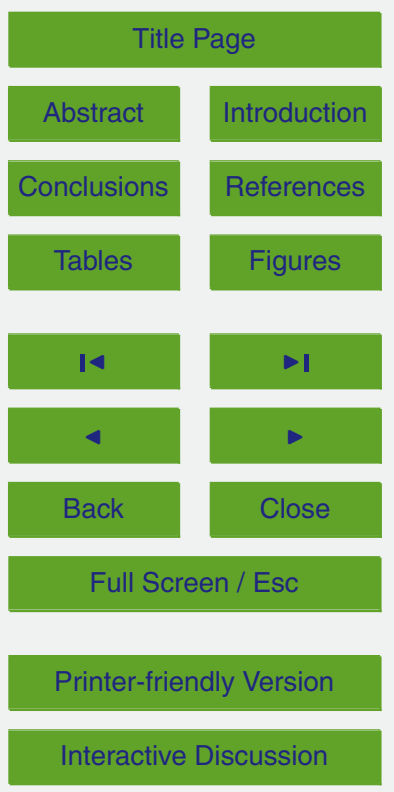


The detector was calibrated against gamma spectroscopy laboratory measurements with a $20 \%$ relative efficiency Li-drifted Ge detector (GeLi; Princeton Gamma-Tech, Princeton, NJ, USA) at the Department for Physics and Astronomy, University of Basel. The resulting measurement uncertainty on ${ }^{137} \mathrm{Cs}$ peak area (at $662 \mathrm{keV}$ ) was lower 5 than $8 \%$ (error of the measurement at 1-sigma). Gamma spectrometry calibration and quality control were performed following the protocol proposed by Shakhashiro and Mabit (2009). A detailed description of the calibration procedure of the in-situ detector is provided by Schaub et al. (2010). For the conversion of the ${ }^{137} \mathrm{Cs}$ inventories to soil erosion rates we used the model as described by Konz et al. (2009).

\subsubsection{Assessment of soil redistribution by water erosion using the RUSLE}

The RUSLE (Wischmeier and Smith, 1978) is an empirical model originally developed in the United States. Several adapted versions for other regions as well as for different temporal resolutions have been developed and applied with more or less success (Kinnell, 2010). Despite its well-known limitation (highlighted in our introduction), we 15 selected RUSLE because of the lack of simple soil erosion models specific for mountain areas and moreover because of its better performance when compared to the other existing models (Konz et al., 2010; Meusburger et al., 2010b). The RUSLE can be calculated using the following equation:

$A=R \cdot K \cdot \mathrm{LS} \cdot C \cdot P$

20 where $A$ is the predicted average annual soil loss $\left(\mathrm{tha}^{-1} \mathrm{yr}^{-1}\right) . R$ is the rainfall- runofferosivity factor $\left(\mathrm{Nh}^{-1}\right)$ that quantifies the effect of raindrop impact and reflects the rate of runoff likely to be associated with the rain (Wischmeier and Smith, 1978). The soil erodibility factor $K\left(\mathrm{Nh} \mathrm{kg} \mathrm{m}^{-2}\right)$ reflects the ease of soil detachment by splash or surface flow. The parameter LS (dimensionless) accounts for the effect of slope length $(L)$ and slope gradient $(S)$ on soil loss. The $C$-factor is the cover factor, which represents the effects of all interrelated cover and management variables (Renard et al., 1997).
HESSD

10, 9505-9531, 2013

Impact of snow gliding on soil redistribution

K. Meusburger et al.

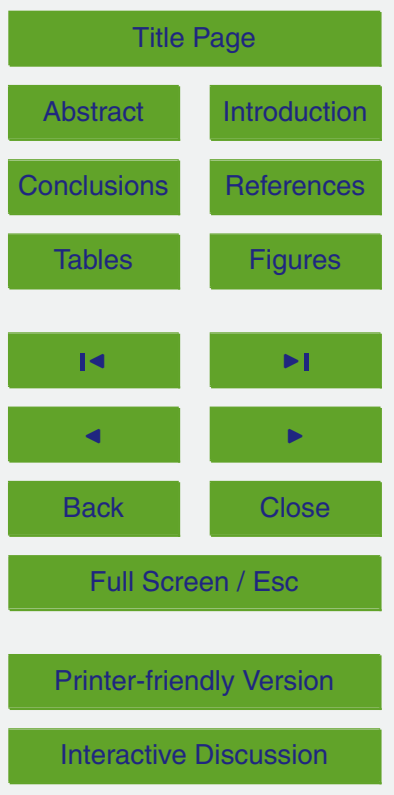


For comparability between the RUSLE estimates of Konz et al. (2009) and the ones assess in this study we used the same $R$ factor of $97 \mathrm{Nh}^{-1}$. The $K$ factor was calculated with the $K$ nomograph after Wischmeier and Smith (1978) using grain-size analyses and carbon contents of the upper $15 \mathrm{~cm}$ of the soil profiles. Total $\mathrm{C}$ content 5 of soils was measured with a Leco CHN analyzer 1000, and grain size-analyses were performed with sieves for grain sizes between 32 and $1000 \mu \mathrm{m}$ and with a Sedigraph 5100 (Micromeritics) for grain sizes between 1 and $32 \mu \mathrm{m}$. $L$ and $S$ were calculated after Renard et al. (1997). The support and practice factor $P$ (dimensionless) was set to 0.9 for some of the pasture sites because alpine pastures with cattle trails resemble 10 small terrace structures, which are suggested to be considered in $P$ (Foster and Highfill, 1983). For all other sites, $P$ value was set to 1 . The cover-and-management factor $C$ was assessed for sites with and without dwarf shrubs separately using measured fractional vegetation cover (FVC) in the field.

For investigated sites without dwarf shrubs (US Department of Agriculture, 1977) the 15

$C=0.45 \cdot \mathrm{e}^{-0.0456 \cdot \mathrm{FVC}}$

for sites with dwarf shrubs the following equation was used:

$C=0.45 \cdot \mathrm{e}^{-0.0324 \cdot \mathrm{FVC}}$

The FVC was determined in April and September using a grid of $1 \mathrm{~m}^{2}$ with a mesh 20 width of $0.1 \mathrm{~m}^{2}$. The visual estimate of each mesh was averaged for the entire square meter. This procedure was repeated four times for each plot. The maximum standard deviation was approx. $5 \%$.

\subsection{Spatial modelling of snow glide distances}

We used the spatial snow glide model (SSGM, Leitinger et al., 2008) to predict potential snow glide distances for an area of approximately $30 \mathrm{~km}^{2}$ surrounding our study sites.

\section{HESSD}

10, 9505-9531, 2013

Impact of snow

gliding on soil

redistribution

K. Meusburger et al.

Title Page

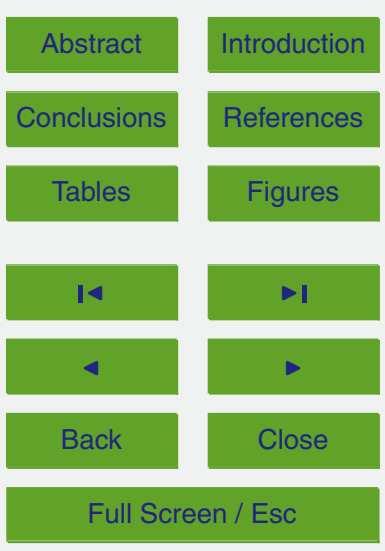

Printer-friendly Version

Interactive Discussion 
The SSGM is an experimental model, which includes 6 main parameters: the forest stand $(0 ; 1)$, the slope angle $\left({ }^{\circ}\right)$, the winter precipitation $(\mathrm{mm})$, the slope exposition $E$ $(0 ; 1)$, the static friction coefficient $\mu_{\mathrm{s}}(-)$ and the slope exposition $W(0 ; 1)$. Slope and aspect were derived from the digital elevation models DHM25 and below 2000 ma.s.I. 5 the DOM (Swisstopo). The DOM is a high precision digital surface model with $2 \mathrm{~m}$ resolution and an accuracy of $\pm 0.5 \mathrm{~m}$ at $1 \sigma$ in open terrain and $\pm 1.5 \mathrm{~m}$ at $1 \sigma$ in terrain with vegetation. The DHM25 has a resolution of $25 \mathrm{~m}$ with an average error of $1.5 \mathrm{~m}$ for the Central Plateau and the Jura, $2 \mathrm{~m}$ for the Pre-Alps and the Ticino and 3 to $8 \mathrm{~m}$ for the Alps (Swisstopo). Winter precipitation was derived from the MeteoSchweiz station 10 located in Andermatt. We used the result from a QuickBird land cover classification with a resolution of $2.4 \mathrm{~m}$ (subsequently resampled to $5 \mathrm{~m}$ ) as land cover input (Meusburger et al., 2010a). Combining this land cover map with a land use map (Meusburger and Alewell, 2009), it was possible to derive the parameter forest stand. To each of the 4 investigated land cover types a uniform static friction coefficient $\left(\mu_{\mathrm{s}}\right)$ was assigned.

The static friction coefficient can be derived by:

$\mu_{\mathrm{s}}=\frac{F_{\mathrm{r}}}{F_{\mathrm{n}}}$

where $F_{\mathrm{n}}$ is the normal force that can be calculated with

$F_{\mathrm{n}}=m \cdot g \cdot \cos \alpha$

where $g$ the gravitational constant $\left(9.81 \mathrm{~m} \mathrm{~s}^{-1}\right), \alpha$ is the slope angle $\left({ }^{\circ}\right)$ and $m$ the weight 20 of the snow glide shoe (in our study $202 \mathrm{~g}$ ).

The initial force $\left(F_{r}\right)$, which is needed to get the glide shoe moving on the vegetation surface, was measured with a spring balance (Pesola ${ }^{\circledR}$ Medio $1000 \mathrm{~g}$ ). To obtain representative values of $F_{\mathrm{r}}$ the measurement was replicated 10 times per sample site and subsequently averaged. The parameter estimates the surface roughness, which integrates the effect of different vegetation types and land uses on snow gliding.
HESSD

10, 9505-9531, 2013

Impact of snow

gliding on soil

redistribution

K. Meusburger et al.

Title Page

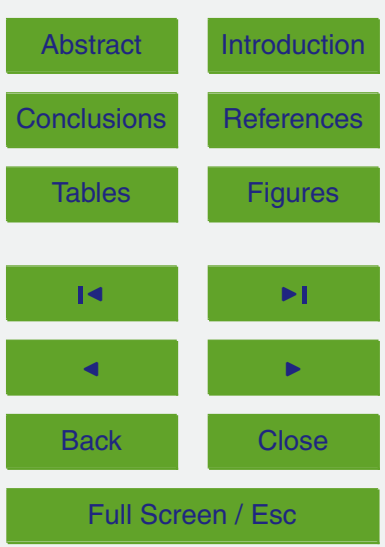

Printer-friendly Version

Interactive Discussion 
A detailed description of the model and its parameters has been provided by Leitinger et al. (2008).

The model was calibrated with the measured snow glide distances and $285 \mathrm{~mm}$ winter precipitation (sum of the precipitation from December 2009 to April 2010). After the 5 calibration, potential snow glide distances with long-term average winter precipitation of $443 \mathrm{~mm}$ (years 1959 to 2010) were modelled.

\section{Results and Discussion}

\subsection{Snow glide measurements 2009/2010}

For each site the static friction coefficient as measure for surface roughness was de10 termined in autumn prior to the installation of the snow glide shoes. Lowest surface roughness was observed for the hayfields, followed by sites covered with Alnus viridis on the north exposed slope, where only little undergrowth was observed (Table 1). For the pastures with dwarf-shrubs, the two mean monitored values differed $(0.04$ and 0.07 ) but were similar to that of pastures without dwarf-shrubs (0.06 to 0.07$)$. Slightly 15 higher values were observed for the dense undergrowth of Alnus viridis sites on the south exposed slope (0.07-0.08).

The measured snow glide distances of the different sites varied from 1 to $189 \mathrm{~cm}$ (see Table 1). A main proportion of this variability can be explained by the slope exposition and the surface roughness (see Fig. 2). With increasing surface roughness (expressed as the static friction coefficient; $\mu_{\mathrm{s}}$ ) the snow glide distance declines. This decrease is more pronounced for the south exposed slope $\left(y=-1547.2 \mu_{\mathrm{s}}+172.93 ; R^{2}=0.50\right.$; $p=0.036$ ). For the north exposed slope the snow glide distances and the variability are lower. Approximately $80 \%$ of the observed variability on the north exposed slope can be explained by the surface roughness $\left(y=-622.17 \mu_{\mathrm{s}}+43.09 ; R^{2}=0.82 ; p=\right.$ $50 \%$ of the variability can be explained by the difference in surface roughness. The

Impact of snow gliding on soil redistribution

K. Meusburger et al.

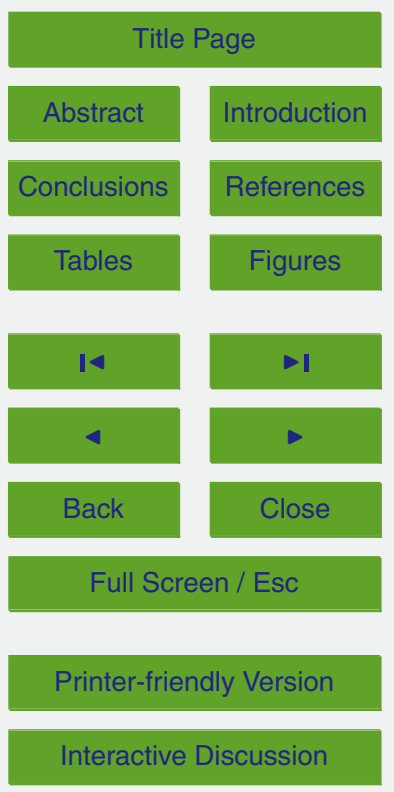


identification of slope exposition and surface roughness as main causal factors for snow gliding, corresponds to the findings of other studies (In der Gand and Zupancic, 1966; Newesely et al., 2000; Hoeller et al., 2009).

Our measured snow glide distances are comparable to those recorded by other re5 searchers. For example Höller et al. (2009) monitored during a seven-year period in the Austrian Alps a snow glide distance of $10 \mathrm{~cm}$ within the forest, $170 \mathrm{~cm}$ in cleared forest sites and up to $320 \mathrm{~cm}$ for open fields. Margreth (2007) found total glide distances of 19 to $102 \mathrm{~cm}$ for an eleven-year observation period in the Swiss East Alps (south-east exposed slope at 1540 ma.s.I.).

\subsection{Soil erosion estimates}

On the north-facing slope an average RUSLE estimate of $3.2 \mathrm{tha}^{-1} \mathrm{yr}^{-1}$ with a maximum value of $7.0 \mathrm{tha}^{-1} \mathrm{yr}^{-1}$ was established (Table 2). The on average lower values as compared to the south-facing slope (Konz et al., 2009) are due to lower slope angles (thus lower LS-factor values) and $C$ factors (due to a higher fractional vegetation cover). on the north exposed slopes. The latter is caused by a $6 \%$ higher proportion of very fine sand.

The mean ${ }^{137} \mathrm{Cs}$ assessed soil erosion rates of $17.7 \mathrm{tha}^{-1} \mathrm{yr}^{-1}$ are three to four times as high as the RUSLE estimates. Also with the ${ }^{137}$ Cs method the average soil erosion rate on the north exposed slope is lower than on the south exposed slopes (by $7.5 \mathrm{tha}^{-1} \mathrm{yr}^{-1}$ ). The highest ${ }^{137} \mathrm{Cs}$-based soil erosion estimates are found for the sites located downslope of the Alnus viridis stands. The higher RUSLE and ${ }^{137} \mathrm{Cs}$ estimates on the more intensely used, steeper and more snow glide affected south exposed slope are reasonable. However, the very high ${ }^{137} \mathrm{Cs}$ erosion rates at the sites below Alnus

\section{HESSD}

10, 9505-9531, 2013

Impact of snow gliding on soil redistribution

K. Meusburger et al.

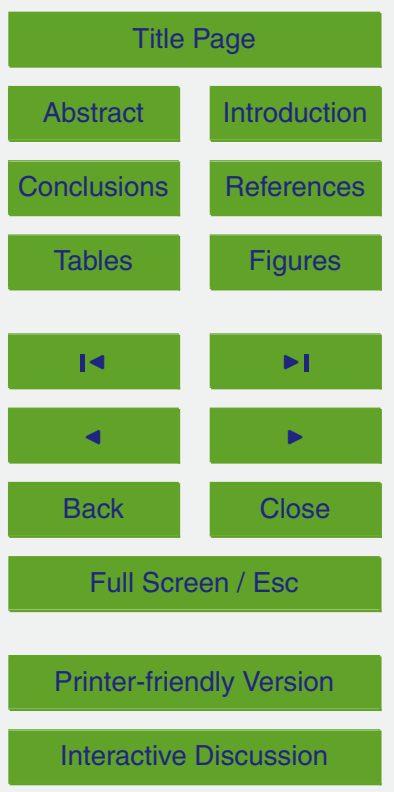




\subsection{Relation between soil redistribution and snow gliding}

Our hypothesis was that the difference of the water soil erosion rate (determined with RUSLE) and the total net erosion (determined with the ${ }^{137}$ Cs method) is related to the winter soil erosion rate mainly caused by snow movement. As such, we assumed 5 a correlation between measured snow glide distance and winter soil erosion rates. However, the correlation between winter erosion and snow glide rates for all sites was weak (Fig. 3). This is mainly due to the Alnus viridis sites that showed a high difference between RUSLE and ${ }^{137} \mathrm{Cs}$ based rates, however, a low snow glide distance. Excluding these plots from the data analysis improved the relationship: $73 \%$ of the variability of the winter soil erosion rate is explained by the measured snow glide distance with a significance of $p<0.005$ (Fig. 3). With increasing snow glide distance also the winter soil erosion rate increased. The observation of increasing soil erosion with increasing snow glide rates is congruent with the findings of Leitinger et al. (2008), who observed that the severity of erosion attributed to snow gliding (e.g. torn out trees, extensive high modelled snow glide distance and vice versa.

The results imply that (i) the observed discrepancies between the RUSLE and ${ }^{137} \mathrm{Cs}$ based soil erosion rates are indeed related to snow gliding, (ii) snow gliding is an important causal factor for soil redistribution in the investigated sites and probably as well for other mountain sites with comparable topographic and climatic conditions. For the Alnus viridis sites, however, we have to expect that either one of the two approaches to determine soil erosion rates is erroneous and/or that we have another predominant erosion process not considered/or correctly parameterised in the RUSLE yet. A possible error related to the ${ }^{137} \mathrm{Cs}$ approach might be that ${ }^{137} \mathrm{Cs}$ was intercepted by leaf and litter material of Alnus viridis differently. Thus, a reference site with Alnus viridis stocking would be necessary, which is difficult to find in our site because flat areas are intensively used. Assuming that the discrepancy between RUSLE and ${ }^{137} \mathrm{Cs}$ based soil

\section{HESSD}

10, 9505-9531, 2013

Impact of snow gliding on soil redistribution

K. Meusburger et al.

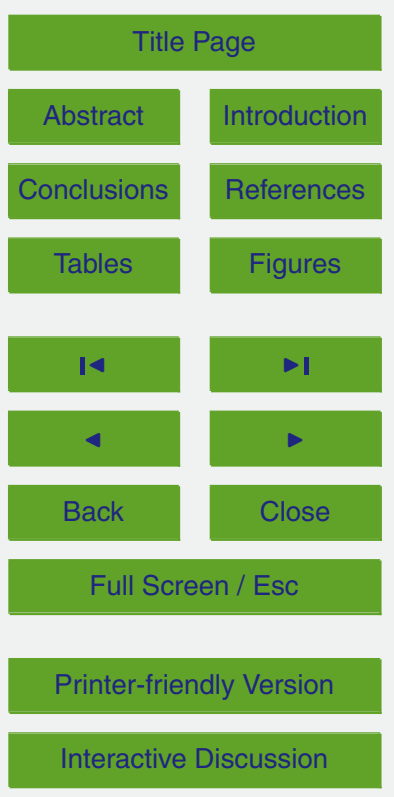


erosion rates corresponds to the winter erosion rates; we can attribute on average (for our sites) $67 \%$ of the total erosion rate to the influence of snow movement.

For our data it can be deduced that low surface roughness is correlated to high snow glide distances and these are again positively correlated to high observed differences 5 between RUSLE and ${ }^{137} \mathrm{Cs}$ based soil erosion rates that we interpret as high winter soil erosion rates. However, the presented relation might be highly variable, depending on soil temperature (whether it is frozen or not) during snow in, the occurrence of a water film that allows a transition of dry to wet gliding (Haefeli, 1948) and on the weather conditions of a specific winter. In addition, some of the investigated sites might also be affected by avalanches in other years.

\subsection{Modelled snow glide distances}

The significant correlation between snow glide distance and "winter" soil erosion rates for grasslands highlights the need to consider the process of snow glide in soil erosion models for steep, scarcely vegetated alpine areas. Therefore, we tested the suitabil15 ity of the empirical Spatial Snow Glide Model (SSGM) for our site (see Fig. 4). The SSGM was able to reproduce the findings from snow glide measurements for the hay meadows and pastures of both slopes. Larger discrepancies occur for the Alnus viridis sites and the pastures with dwarf shrubs. Sites exposed to the north revealed generally lower modelled snow glide distances.

$20 \quad$ Modelled results partly reproduce the relative differences between the land use types observed in the winter 2009/2010. Exceptional are the higher snow glide distances for sites covered with Alnus viridis on the south exposed slope, as the potential of Alnus viridis for stabilization regarding snow gliding is usually high (Newesely et al., 2000; Leitinger et al., 2008), which was confirmed with the measured data. On the other 25 hand, the high discrepancy between RUSLE and ${ }^{137} \mathrm{Cs}$ soil erosion rates points towards a high winter related soil erosion rate and thus snow glide distance (as predicted by the model). Our database allows no final interpretation. Further investigations will be needed to resolve the snow glide and soil erosion questions of the Alnus viridis sites.

Impact of snow gliding on soil redistribution

K. Meusburger et al.

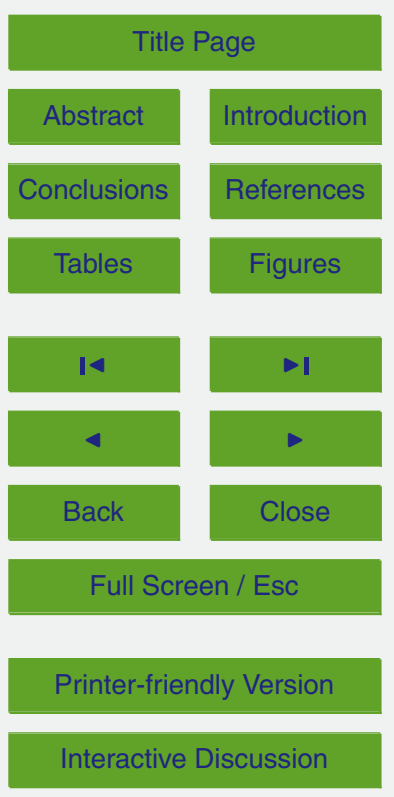


The modelled snow glide distance map (Fig. 5) is based on the long-term average of winter precipitation, which is with $443 \mathrm{~mm}$ clearly higher than the winter precipitation in $2009 / 2010$ with $285 \mathrm{~mm}$. Highest snow glide values can be expected on the steep rock covered, south exposed slopes. Very high rates are also found on the lower parts of 5 the south exposed slopes that are used as pastures and hayfields. The smallest snow glide rates are located on the north exposed slopes with Alnus viridis stocking. The map clearly reproduces the effect of topography and exposition. Snow glide distances summarized for predominant land-use types also show the impact of vegetation cover (Fig. 6).

10 The highest values occur for the south-exposed Alnus viridis sites, which might be largely attributed to the preferred growing conditions on steep slopes that generally foster snow gliding. North exposed hay meadows and pastures also reveal a high potential for snow glide distances. According to several studies on the seasonal snow-earth interface conditions (In der Gand and Zupancic, 1966; McClung and Clarke, 1987;

Leitinger et al., 2008), snow gliding on south-exposed sites is preferential in spring, when high solar radiation leads to a high portion of melting water at the interface. However, in autumn snow gliding primarily occurs when a huge amount of snow falls on the warm soil. In this case, north-exposed sites may be confronted with high snow gliding activity as well.

It should be mentioned that the SSGM yields potential maximum snow glide distances. If conditions for maximum glide distances are achieved in a specific winter depends on several external factors (such as the formation of a free water between soil and snow layer, etc.), which are highly dynamic and therefore not represented by the SSGM. The topographic and climatic conditions resemble to the environment under which the SSGM was initially developed, nonetheless further regular yearly measurement would be needed to finally validate the performance of the model in this area. In general, the application of the SSGM highlighted the relevance of the snow gliding process and the potentially related soil erosion for (sub-)alpine areas.

\section{HESSD}

10, 9505-9531, 2013

Impact of snow gliding on soil redistribution

K. Meusburger et al.

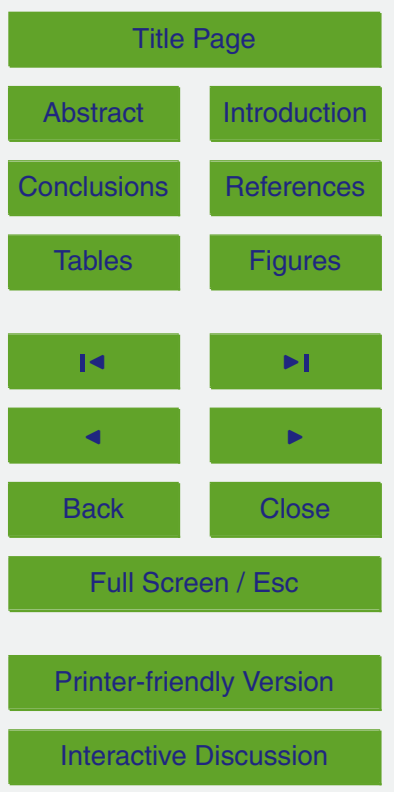




\section{Conclusions}

For grasslands the difference between RUSLE and ${ }^{137} \mathrm{Cs}$ based soil erosion rates could be explained by the influence of snow gliding. Our study highlights that a large proportion (for our sites on average $67 \%$ ) of the annual soil loss is due to snow movement 5 - here snow gliding. Thus, for correct soil erosion prediction in high mountain areas it is important to assess and quantify the erosivity of snow movement and also snow melt (not considered in this study). The Spatial Snow Glide Model might serve as a tool to evaluate the spatial relevance of snow gliding for larger areas. However, it would be desirable in addition to estimate the kinetic energy that acts upon the soil related to the snow movement. This would allow for a direct comparison of rainfall erosivity and snow movement erosivity and moreover its insertion in soil erosion risk models. The impact of snow movement on soil removal should, moreover be evaluated in context of predicted changes in snow cover e.g. an increase of snow amount for elevated (> 2000 ma.s.l.) areas (Beniston, 2006).

15 Further we demonstrated that surface roughness reduces snow glide rates and in turn snow glide rates are positively related to increasing soil loss for grassland sites. This is an important result with respect to soil conservation strategy since surface roughness can be modified and adapted through an effective land use management.

Acknowledgements. This study was funded by the Swiss Federal Office for the Environment 20 (Contract-no.: StoBoBio/810.3129.004/05/0X).

\section{References}

Ackroyd, P.: Erosion by snow avalanche and implications for geomorphic stability, Torlesse Range, New-Zealand, Arct. Alp. Res., 19, 65-70, doi:10.2307/1551001, 1987.

Alewell, C., Meusburger, K., Juretzko, G., Mabit, L., and Ketterer, M.: Suitability of ${ }^{239+240} \mathrm{Pu}$ as 25 a tracer for soil erosion in alpine grasslands, Chemosphere, in preparation, 2013.

Bell, I., Gardner, J., and Descally, F.: An estimate of snow avalanche debris transport, Kaghan Valley, Himalaya, Pakistan, Arct. Alp. Res., 22, 317-321, doi:10.2307/1551594, 1990.

\section{9}

HESSD

10, 9505-9531, 2013

Impact of snow

gliding on soil

redistribution

K. Meusburger et al.

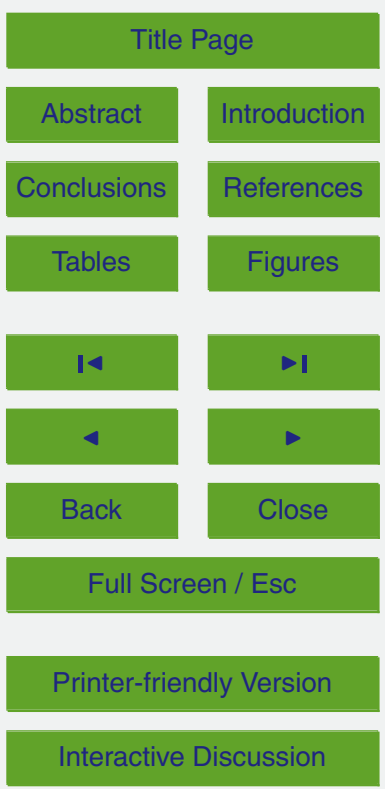


Beniston, M.: Mountain weather and climate: a general overview and a focus on climatic change in the Alps, Hydrobiologica, 562, 3-16, 2006.

Benmansour, M., Mabit, L., Nouira, A., Moussadek, R., Bouksirate, H., Duchemin, M., and Benkdad, A.: Assessment of soil erosion and deposition rates in a Moroccan agricultural 5 field using fallout $137 \mathrm{Cs}$ and $210 \mathrm{Pbex}$, Journal of Environmental Radioactivity, 115, 97-106, doi:10.1016/j.jenvrad.2012.07.013, 2013.

Ceaglio, E., Meusburger, K., Freppaz, M., Zanini, E., and Alewell, C.: Estimation of soil redistribution rates due to snow cover related processes in a mountainous area (Valle d'Aosta, NW Italy), Hydrol. Earth Syst. Sci., 16, 517-528, doi:10.5194/hess-16-517-2012, 2012.

10 Confortola, G., Maggioni, M., Freppaz, M., and Bocchiola, D.: Modelling soil removal from snow avalanches: a case study in the North-Western Italian Alps, Cold Reg. Sci. Technol., 70, 4352, doi:10.1016/j.coldregions.2011.09.008, 2012.

Foster, G. R. and Highfill, R. E.: Effect of terraces on soil loss - USLE P-factor values for terraces, J. Soil Water Conservat., 38, 48-51, 1983.

Freppaz, M., Godone, D., Filippa, G., Maggioni, M., Lunardi, S., Williams, M. W., and Zanini, E.: Soil erosion caused by snow Avalanches: a case study in the Aosta Valley (NW Italy), Arct. Antarct. Alp. Res., 42, 412-421, doi:10.1657/1938-4246-42.4.412, 2010.

Fuchs, S. and Keiler, M.: Variability of Natural Hazard Risk in the European Alps: Evidence from Damage Potential Exposed to Snow Avalanches, Disaster Mangement Handbook, edited by:

20 Pinkowski, J., Crc Press-Taylor \& Francis Group, Boca Raton, 267-279, 2008.

Gardner, J. S.: Observations on erosion by wet snow avalanches, Mount Rae area, Alberta, Canada, Arct. Alp. Res., 15, 271-274, doi:10.2307/1550929, 1983.

Haefeli, R.: Schnee, Lawinen, Firn und Gletscher, Ingenieur-Geologie, edited by: Bendel, L., Wien, 1948.

Heckmann, T., Wichmann, V., and Becht, M.: Sediment transport by avalanches in the Bavarian Alps revisited - a perspective on modelling, in: Geomorphology in Environmental Application, edited by: Schmidt, K. H., Becht, M., Brunotte, E., Eitel, B., and Schrott, L., Zeitschrift Fur Geomorphologie Supplement Series, Gebruder Borntraeger, Stuttgart, 11-25, 2005.

Hoeller, P., Fromm, R., and Leitinger, G.: Snow forces on forest plants due to creep and glide, Forest Ecol. Manag., 257, 546-552, doi:10.1016/j.foreco.2008.09.035, 2009.

In der Gand, H. R. and Zupancic, M.: Snow gliding and avalanches, IAHS-AISH Publ., 69, 230242, 1966.

HESSD

$10,9505-9531,2013$

Impact of snow gliding on soil redistribution

K. Meusburger et al.

Title Page

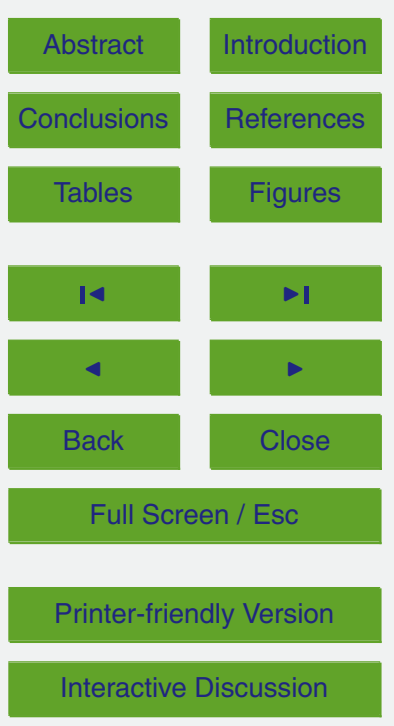


Jomelli, V. and Bertran, P.: Wet snow avalanche deposits in the French Alps: Structure and sedimentology, Geogr. Ann. Ser. A, 83, 15-28, doi:10.1111/j.0435-3676.2001.00141.x, 2001.

Juretzko, G.: Quantifizierung der Bodenerosion mit 137Cs und USLE in einem alpinen Hochtal (Val Piora, CH), Master, Environmental Sciences, Basel, Basel, 1-152, 2010.

5 Kinnell, P. I. A.: Why the universal soil loss equation and the revised version of it do not predict event erosion well, Hydrol. Process., 19, 851-854, doi:10.1002/hyp.5816, 2005.

Kinnell, P. I. A.: Event soil loss, runoff and the universal soil loss equation family of models: a review, J. Hydrol., 385, 384-397, doi:10.1016/j.jhydrol.2010.01.024, 2010.

Konz, N., Schaub, M., Prasuhn, V., Bänninger, D., and Alewell, C.: Cesium-137-based erosionrate determination of a steep mountainous region, J. Plant Nutr. Soil Sci., 172, 615-622, doi:10.1002/jpln.200800297, 2009.

Konz, N., Baenninger, D., Konz, M., Nearing, M., and Alewell, C.: Process identification of soil erosion in steep mountain regions, Hydrol. Earth Syst. Sci., 14, 675-686, doi:10.5194/hess14-675-2010, 2010.

Konz, N., Prasuhn, V., and Alewell, C.: On the measurement of alpine soil erosion, Catena, 91, 63-71, doi:10.1016/j.catena.2011.09.010, 2012.

Leitinger, G., Holler, P., Tasser, E., Walde, J., and Tappeiner, U.: Development and validation of a spatial snow-glide model, Ecol. Model., 211, 363-374, doi:10.1016/j.ecolmodel.2007.09.015, 2008.

20 Mabit, L. and Bernard, C.: Assessment of spatial distribution of fallout radionuclides through geostatistics concept, J. Environ. Radioact., 97, 206-219, doi:10.1016/j.jenvrad.2007.05.008, 2007.

Mabit, L., Bernard, C., Laverdiere, M. R., Wicherek, S., Garnier, J., and Mouchel, J. M.: Assessment of soil erosion in a small agricultural basin of the St. Lawrence River watershed,

25 Hydrobiologia, 410, 263-268, 1999.

Mabit, L., Bernard, C., and Laverdiere, M. R.: Quantification of soil redistribution and sediment budget in a Canadian watershed from fallout caesium-137 (Cs-137) data, Can. J. Soil Sci., 82, 423-431, 2002.

Mabit, L., Benmansour, M., and Walling, D. E.: Comparative advantages and limitations of the fallout radionuclides $\mathrm{Cs}-137, \mathrm{~Pb}-210$ (ex) and $\mathrm{Be}-7$ for assessing soil erosion and sedimentation, J. Environ. Radioact., 99, 1799-1807, doi:10.1016/j.jenvrad.2008.08.009, 2008.

HESSD

10, 9505-9531, 2013

Impact of snow gliding on soil redistribution

K. Meusburger et al.

Title Page

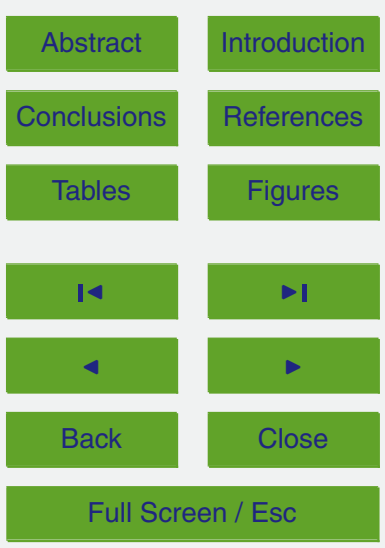

Printer-friendly Version

Interactive Discussion 
Mabit, L., Meusburger, K., Fulajtar, E., and Alewell, C.: The usefulness of ${ }^{137} \mathrm{Cs}$ as a tracer for soil erosion assessment: a critical reply to Parsons and Foster (2011), Earth-Sci. Rev., doi:10.1016/j.earscirev.2013.05.008, accepted, 2013.

Matisoff, G. and Whiting, P. J.: Measuring Soil Erosion Rates Using Natural (Be-7, Pb-210) and Anthropogenic (Cs-137, Pu-239,Pu-240) Radionuclides, Handbook of Environmental Isotope Geochemistry, Vols 1 and 2, edited by: Baskaran, M., Springer-Verlag Berlin, Berlin, 487519, 2011.

McClung, D. M. and Clarke, G. K. C.: The effects of free-water on snow gliding, J. Geophys. Res.-Sol. Ea., 92, 6301-6309, 1987.

10 Merritt, W. S., Letcher, R. A., and Jakeman, A. J.: A review of erosion and sediment transport models, Environ. Modell. Softw., 18, 761-799, doi:10.1016/S1364-8152(03)00078-1, 2003.

Meusburger, K. and Alewell, C.: On the influence of temporal change on the validity of landslide susceptibility maps, Nat. Hazards Earth Syst. Sci., 9, 1495-1507, doi:10.5194/nhess-9-14952009, 2009.

15 Meusburger, K., Banninger, D., and Alewell, C.: Estimating vegetation parameter for soil erosion assessment in an alpine catchment by means of QuickBird imagery, Int. J. Appl. Earth Obs. Geoinf., 12, 201-207, doi:10.1016/j.jag.2010.02.009, 2010a.

Meusburger, K., Konz, N., Schaub, M., and Alewell, C.: Soil erosion modelled with USLE and PESERA using QuickBird derived vegetation parameters in an alpine catchment, Int. J. Appl. Earth Obs. Geoinf., 12, 208-215, doi:10.1016/j.jag.2010.02.004, 2010b.

Meusburger, K., Mabit, L., Park, J.-H., Sandor, T., and Alewell, C.: Combined use of stable isotopes and fallout radionuclides as soil erosion indicators in a forested mountain site, South Korea, Biogeosciences Discuss., 10, 2565-2589, doi:10.5194/bgd-10-2565-2013, 2013.

Nearing, M., Foster, G., Lane, L., and Finkner, S.: A process-based soil erosion model for USDA - water erosion prediction project technology, T. Am. Soc. Agr. Eng., 32, 1587-1593, 1989.

Newesely, C., Tasser, E., Spadinger, P., and Cernusca, A.: Effects of land-use changes on snow gliding processes in alpine ecosystems, Basic Appl. Ecol., 1, 61-67, doi:10.1078/1439-179100009, 2000.

Parker, S. P.: McGraw-Hill Dictionary of Scientific and Technical Terms, The McGraw-Hill Companies, Inc., New York City, 2002.

Renard, K. G., Foster, G. R., Weesies, G. A., MCCool, D. K., and Yoder, D. C.: Predicting soil erosion by water; a guide to conservation planning with the revised universal soil loss equation (RUSLE), US Department of Agriculture, 404, 1997.

\section{HESSD}

10, 9505-9531, 2013

Impact of snow gliding on soil redistribution

K. Meusburger et al.

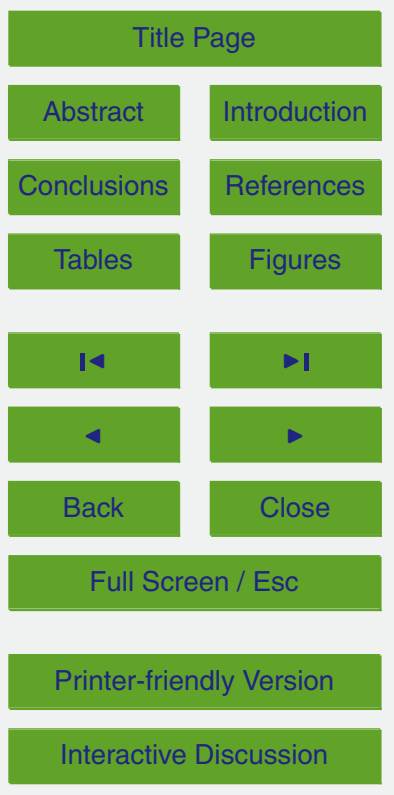


Risse, L. M., Nearing, M. A., Nicks, A. D., and Laflen, J. M.: Error assessment in the universal soil loss equation, Soil Sci. Soc. Am. J., 57, 825-833, 1993.

Smith, S. J., Williams, J. R., Menzel, R. G., and Coleman, G. A.: Prediction of sediment yield from Southern Plains grasslands with the Modified Universal Soil Loss Equation, J. Range Manage., 37, 295-297, doi:10.2307/3898697, 1984.

Wischmeier, W. H. and Smith, D. D.: Predicting rainfall-erosion losses from cropland east of the Rocky Mountains, Washington DC, 1965.

Wischmeier, W. H. and Smith, D. D.: Predicting Rainfall Erosion Losses - A Guide to Conservation Planning. Agric. Handbook No. 537, Washington DC, 58, 1978.

Impact of snow gliding on soil redistribution

K. Meusburger et al.

Title Page

Abstract

\section{Full Screen / Esc}




\section{HESSD}

10, 9505-9531, 2013

\section{Impact of snow gliding on soil redistribution}

Table 1. Parameters related to snow glide distance (sgd) for the investigation sites in the Ursern Valley, Switzerland. $\mathrm{N}$ indicates the sites on the north exposed slope.

\begin{tabular}{|c|c|c|c|c|c|}
\hline Site & Vegetation & Slope $\left({ }^{\circ}\right)$ & Initial Force $F_{r}(g)$ & Static Friction Coefficient $\mu_{\mathrm{s}}(-)$ & Measured sgd $(\mathrm{cm}$ \\
\hline h1 & hayfield & 39 & 58 & 0.04 & 189 \\
\hline h2 & hayfield & 38 & 52 & 0.03 & 50 \\
\hline h3 & hayfield & 35 & 40 & 0.02 & 126 \\
\hline p1 & pasture & 38 & 105 & 0.07 & 34 \\
\hline p2 & pasture & 35 & 114 & 0.07 & 28 \\
\hline pw1 & pasture with dwarf-shrubs & 38 & 59 & 0.04 & 89 \\
\hline pw2 & pasture with dwarf-shrubs & 35 & 113 & 0.07 & 64 \\
\hline $\mathrm{h} 1 \mathrm{~N}$ & hayfield & 28 & 35 & 0.02 & 30 \\
\hline h2N & hayfield & 30 & 46 & 0.03 & 28 \\
\hline $\mathrm{pN}$ & pasture & 25 & 107 & 0.06 & 17 \\
\hline $\mathrm{A} 1 \mathrm{~N}$ & Alnus viridis & 18 & 64 & 0.03 & 2 \\
\hline $\mathrm{A} 2 \mathrm{~N}$ & Alnus viridis & 30 & 62 & 0.04 & 8 \\
\hline $\mathrm{A} 1$ & Alnus viridis & 22 & 158 & 0.08 & 14 \\
\hline $\mathrm{A} 2$ & Alnus viridis & 31 & 122 & 0.07 & 60 \\
\hline
\end{tabular}

Title Page

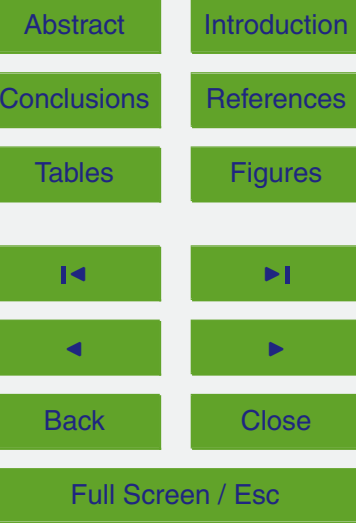

Printer-friendly Version

Interactive Discussion 


\section{HESSD}

10, 9505-9531, 2013

Impact of snow gliding on soil redistribution

K. Meusburger et al.

Table 2. Measured site characteristics $(\mathrm{SOC}=$ soil organic carbon; vfs = very fine sand fraction), resulting RUSLE factors and soil erosion rates and ${ }^{137} \mathrm{Cs}$ based erosion rates for the investigation sites in the Ursern Valley, Switzerland. Mean of south exposed sites was used from Konz et al. (2009).

\begin{tabular}{|c|c|c|c|c|c|c|c|c|c|c|c|c|}
\hline Site & $\begin{array}{l}\text { Slope } \\
\left({ }^{\circ}\right)\end{array}$ & $\begin{array}{l}\mathrm{SOC} \\
(\%)\end{array}$ & $\begin{array}{l}\text { vfs } \\
(\%)\end{array}$ & $\begin{array}{l}\text { silt } \\
(\%)\end{array}$ & $\begin{array}{l}\text { clay } \\
(\%)\end{array}$ & $\begin{array}{l}K \text { factor } \\
\left(\text { thha }^{-1} \mathrm{~N}^{-1}\right)\end{array}$ & $\begin{array}{l}R \text { factor } \\
\left(\mathrm{Nh}^{-1}\right)\end{array}$ & $\begin{array}{l}P \text { factor } \\
(-)\end{array}$ & $\begin{array}{l}\text { LS-factor } \\
(-)\end{array}$ & $\begin{array}{l}C \text { factor } \\
(-)\end{array}$ & $\begin{array}{l}\text { RUSLE } \\
\left(\mathrm{tha}^{-1} \mathrm{yr}^{-1}\right)\end{array}$ & $\begin{array}{l}{ }^{137} \mathrm{Cs} \\
\left(\mathrm{tha}^{-1} \mathrm{yr}^{-1}\right)\end{array}$ \\
\hline h1N & 28 & 4.8 & 18.5 & 41.0 & 5.8 & 0.416 & 97 & 1.00 & 7.0 & 0.012 & 8.0 & 18.3 \\
\hline h2N & 30 & 4.3 & 13.7 & 48.0 & 8.5 & 0.419 & 97 & 1.00 & 8.4 & 0.003 & 2.2 & 7.5 \\
\hline $\mathrm{pN}$ & 18 & 6.2 & 17.5 & 38.7 & 10.2 & 0.369 & 97 & 1.00 & 1.1 & 0.012 & 0.9 & 7.2 \\
\hline $\mathrm{A} 1 \mathrm{~N}$ & 25 & 3.8 & 16.1 & 43.8 & 9.7 & 0.399 & 97 & 1.00 & 5.3 & 0.003 & 1.5 & 16.6 \\
\hline A2N & 30 & 6.8 & 18.7 & 39.7 & 9.6 & 0.389 & 97 & 1.00 & 8.4 & 0.012 & 6.5 & 13.7 \\
\hline $\mathrm{A} 3 \mathrm{~N}$ & 18 & 6.2 & 17.5 & 38.7 & 10.2 & 0.369 & 97 & 1.00 & 1.1 & 0.003 & 0.2 & 20.1 \\
\hline Mean of north sites & 25 & 5.3 & 17.0 & 41.6 & 9.0 & 0.393 & 97 & 1.00 & 5.2 & 0.007 & 3.2 & 13.9 \\
\hline Mean of south sites & 37 & 7.3 & 10.9 & 50.1 & 14.0 & 0.267 & 97 & 0.94 & 14.7 & 0.021 & 7.0 & 21.4 \\
\hline
\end{tabular}

Title Page

Abstract

Introduction

Conclusions

References

Tables

Figures

14

4

Back

Full Screen / Esc

Printer-friendly Version

Interactive Discussion 


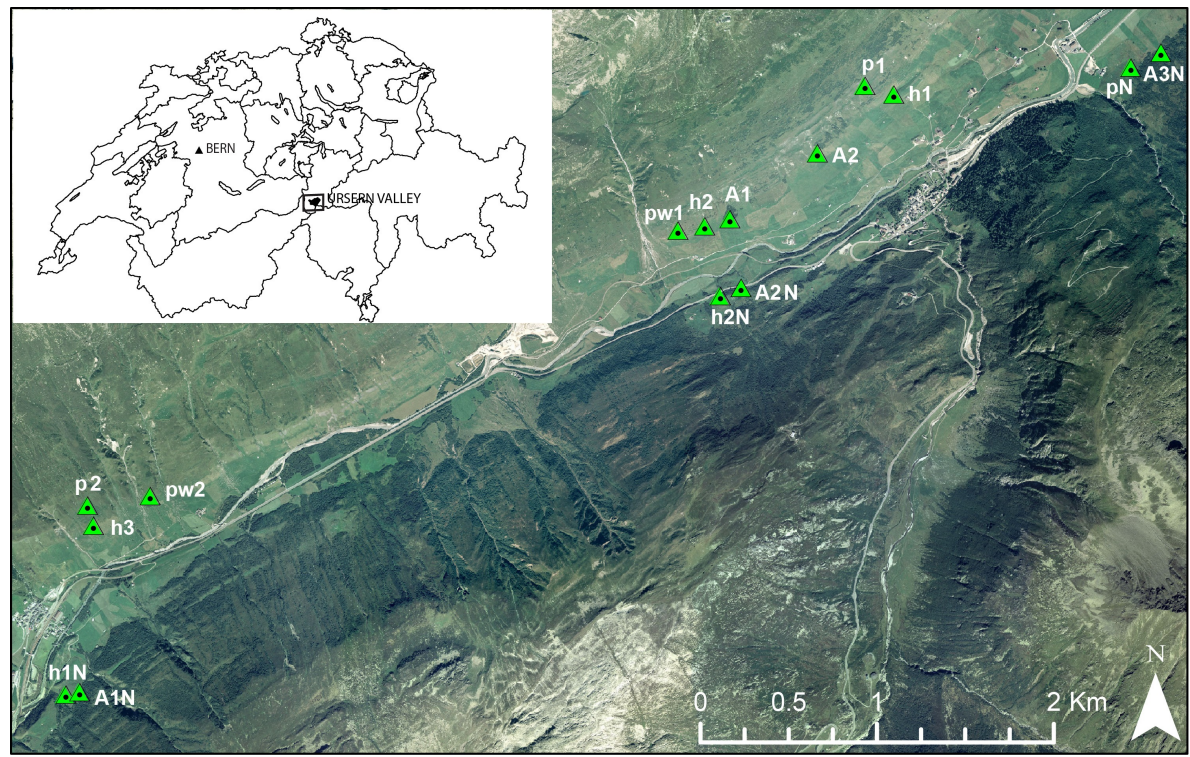

\section{HESSD}

10, 9505-9531, 2013

\section{Impact of snow gliding on soil redistribution}

K. Meusburger et al.

Title Page

Abstract Introduction

Conclusions References

Tables

Figures

14

$\checkmark$

Fig. 1. The Ursern Valley in the Central Swiss Alps and the location of the investigated sites (hayfields $(\mathrm{h})$, pastures $(\mathrm{p})$, pastures with dwarf shrubs (pw), and abandoned grassland covered with Alnus viridis $(\mathrm{A})$, north exposed slope $(\mathrm{N})$ ). Please not that no soil erosion measurements are available for the sites $\mathrm{A} 1$ and $\mathrm{A} 2$ and no snow glide measurements for site $\mathrm{A} 3 \mathrm{~N}$. 


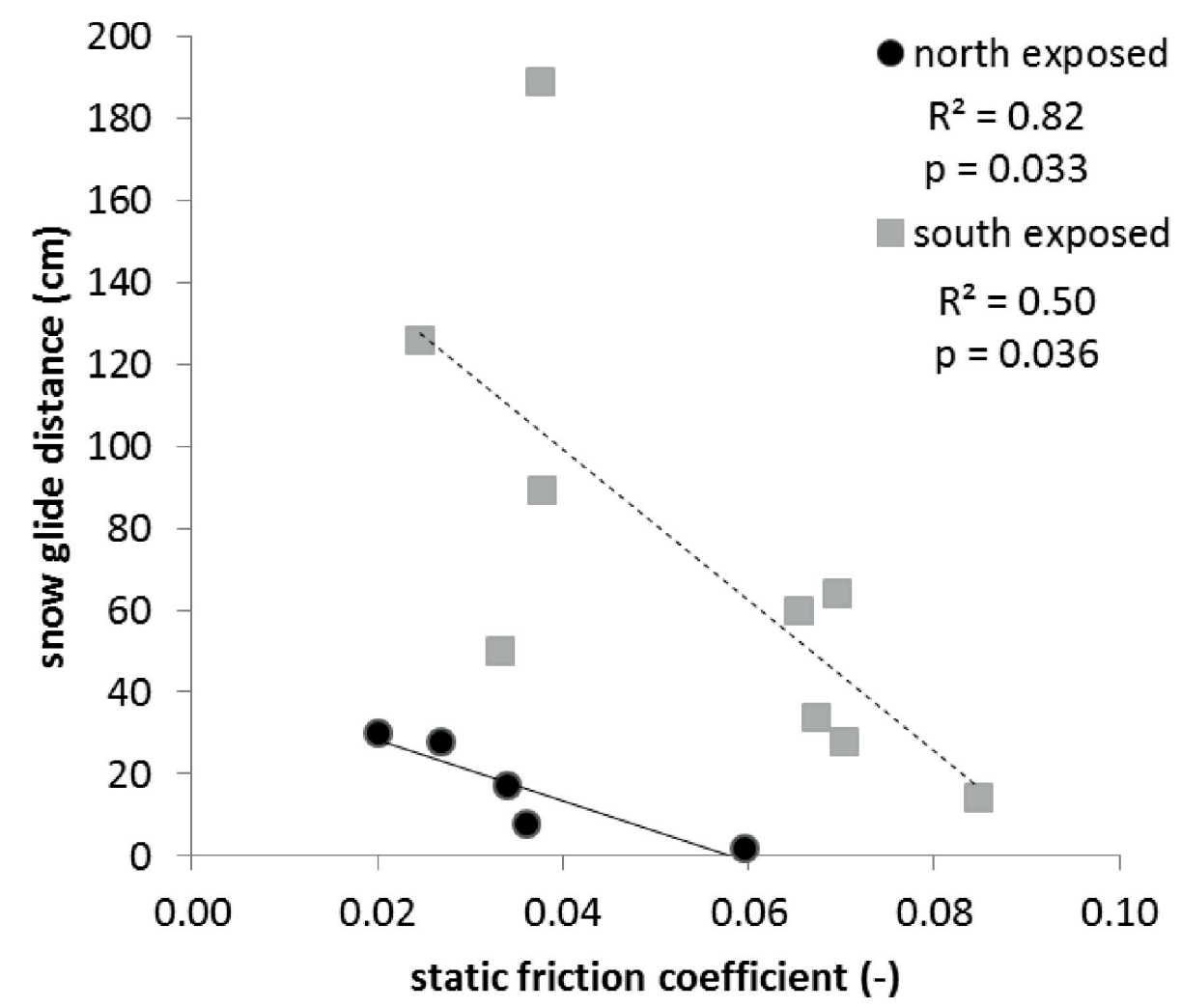

Fig. 2. Snow glide distance against the static friction coefficient for the south- (squares) and north (dots) exposed slope sites.

\section{HESSD}

10, 9505-9531, 2013

Impact of snow gliding on soil redistribution

K. Meusburger et al.

Title Page

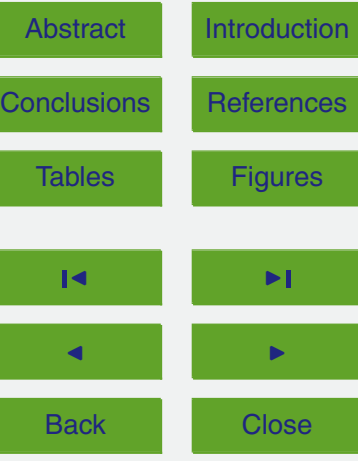

Full Screen / Esc

Printer-friendly Version

Interactive Discussion 


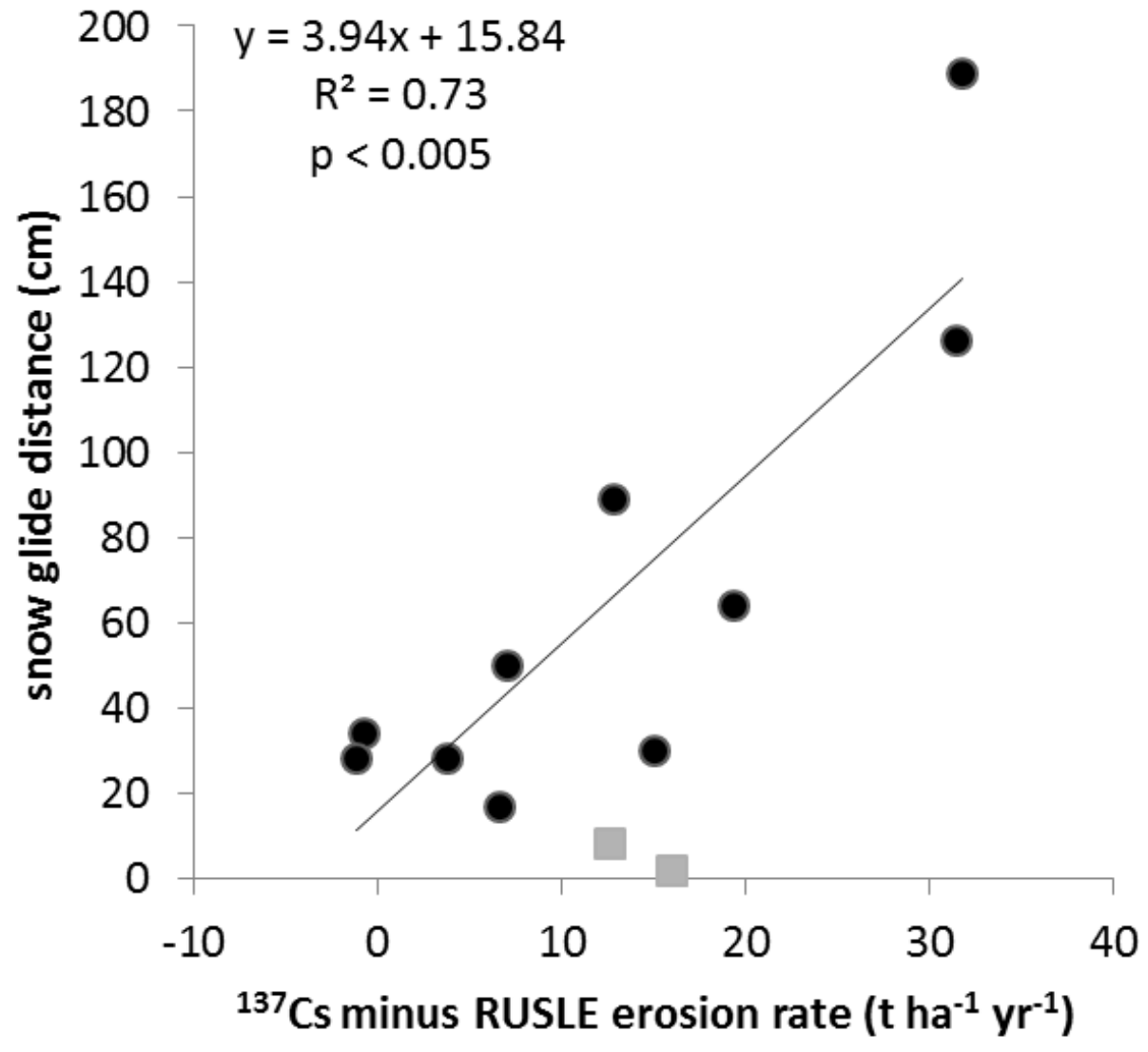

Fig. 3. Correlation of the cumulative snow glide distances $(\mathrm{cm})$ measured for the winter 2009/2010 versus the difference of the ${ }^{137} \mathrm{Cs}$ and RUSLE soil erosion rate (tha ${ }^{-1} \mathrm{yr}^{-1}$ ) for the grassland sites (dots, $n=10$ ) and Alnus viridis sites (squares, $n=2$ ).

\section{HESSD}

10, 9505-9531, 2013

Impact of snow gliding on soil redistribution

K. Meusburger et al.

Title Page

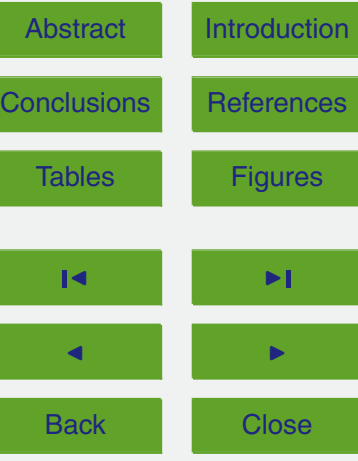

Full Screen / Esc

Printer-friendly Version

Interactive Discussion 


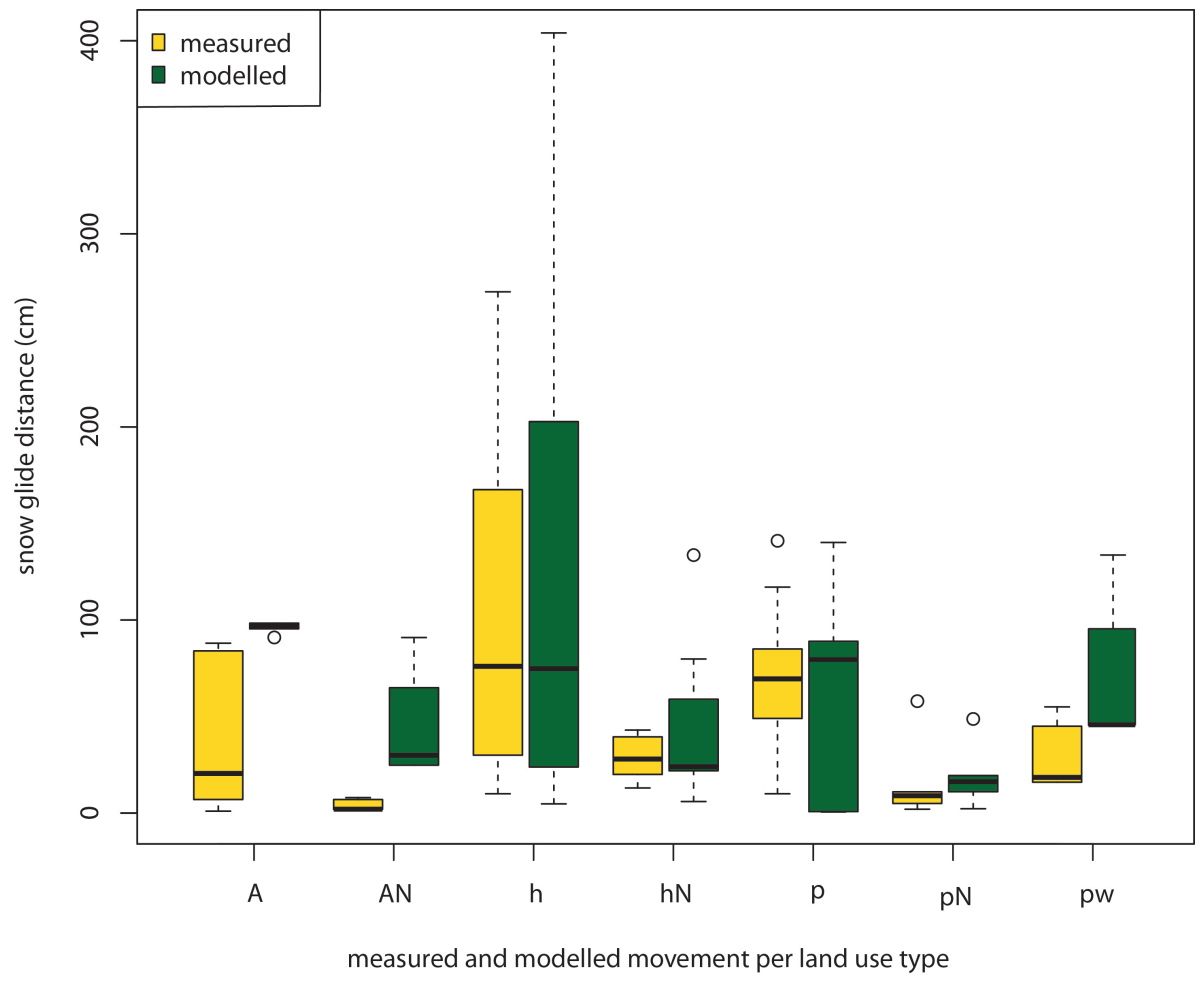

Fig. 4. Measured snow glide distances and corresponding modelling results for different land use/cover types (hayfields (h), pastures ( $p$ ), pastures with dwarf shrubs (pw), and abandoned grassland covered with Alnus viridis (A)) for the winter period 2009/2010. N indicates the sites on the north exposed slope.

\section{HESSD}

10, 9505-9531, 2013

Impact of snow gliding on soil redistribution

K. Meusburger et al.

\section{Title Page}

Abstract

Introduction

Conclusions

References

Tables

Figures

14

$\rightarrow$

4

Back

Close

\section{Full Screen / Esc}

Printer-friendly Version

Interactive Discussion 


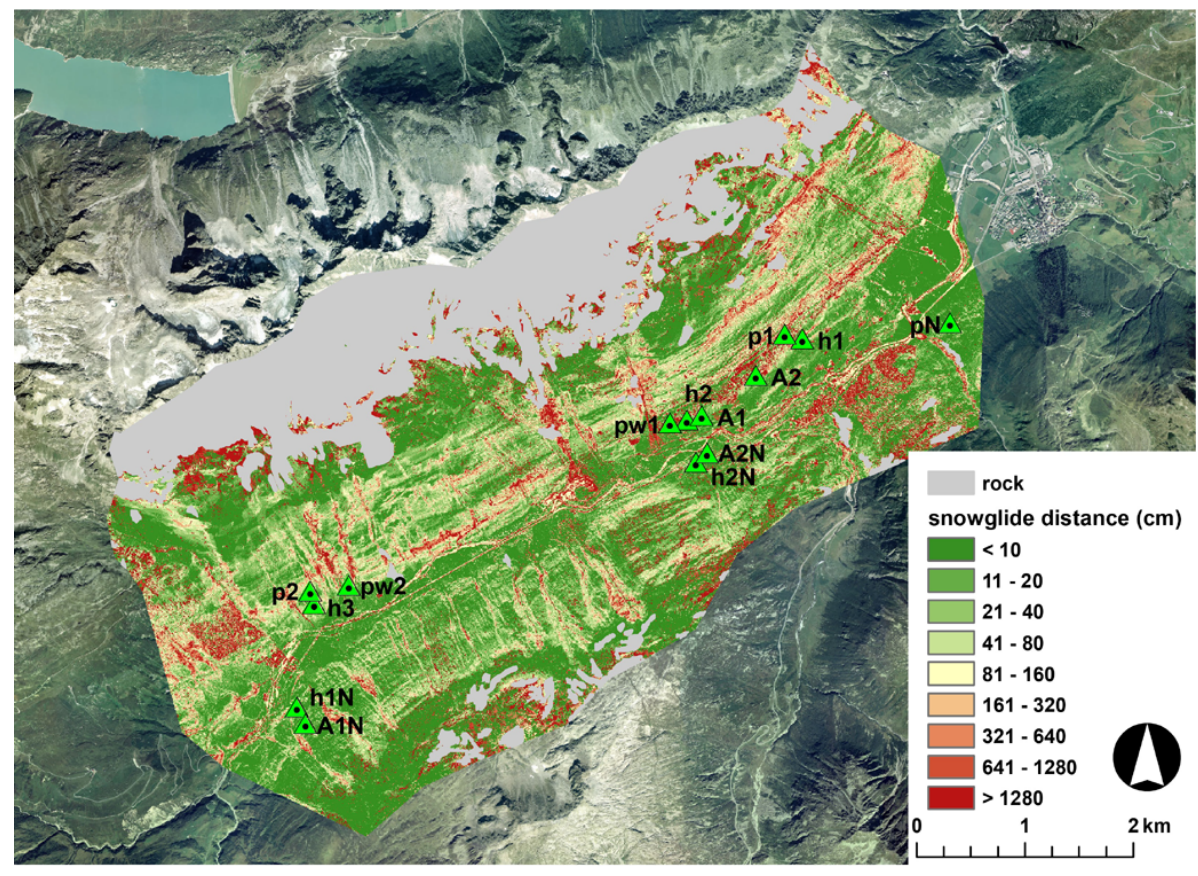

\section{HESSD}

10, 9505-9531, 2013

Impact of snow gliding on soil redistribution

K. Meusburger et al.

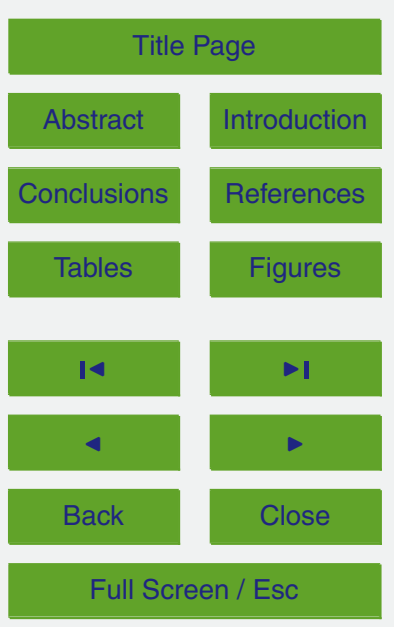

Fig. 5. Potential total snow glide distance $(\mathrm{m})$ modelled with the SSGM.

Printer-friendly Version

Interactive Discussion 


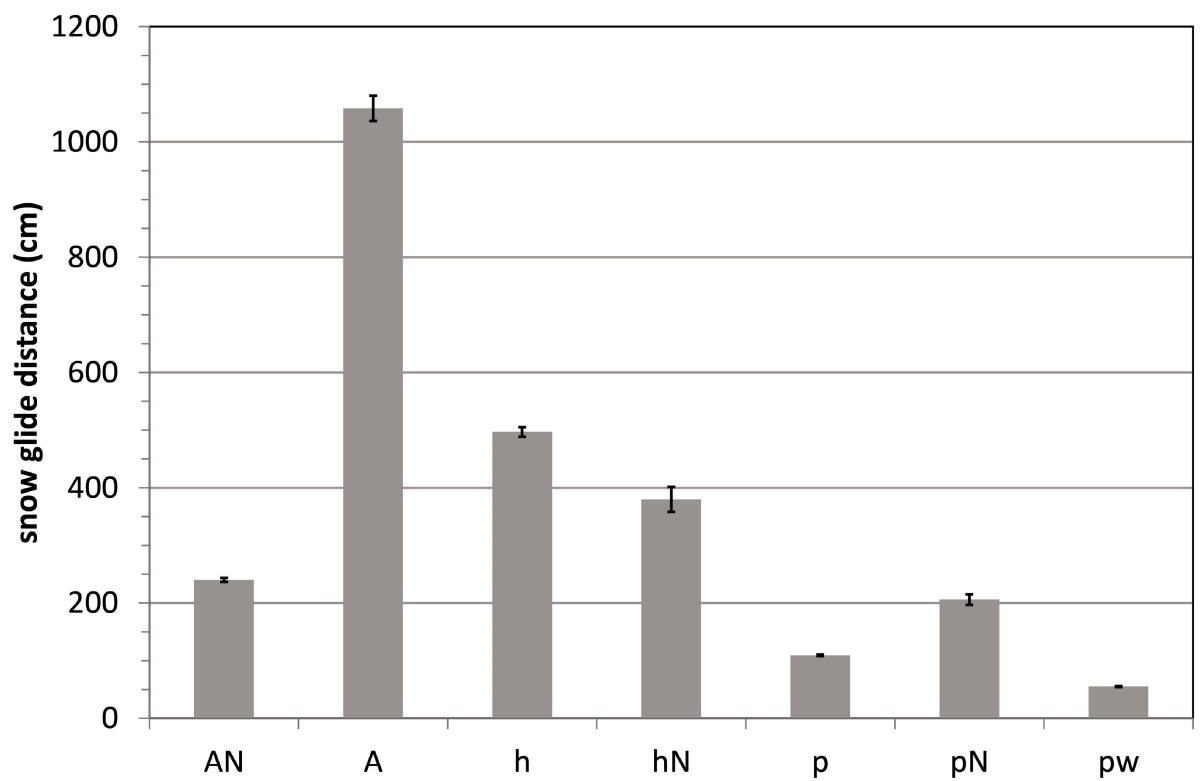

Fig. 6. Mean modelled snow glide distances (winter sum with standard error) as mean for the hole catchment grouped by predominant land-use/cover types (hayfields $(h)$, pastures $(p)$, pastures with dwarf shrubs (pw), Alnus viridis sites (A)). $\mathrm{N}$ indicates the sites on the north exposed slope.

\section{HESSD}

10, 9505-9531, 2013

\section{Impact of snow gliding on soil redistribution}

K. Meusburger et al.

\section{Title Page}

Abstract Introduction

Conclusions References

Tables Figures

14 $\rightarrow 1$

4

Back

Close

\section{Full Screen / Esc}

Printer-friendly Version

Interactive Discussion 